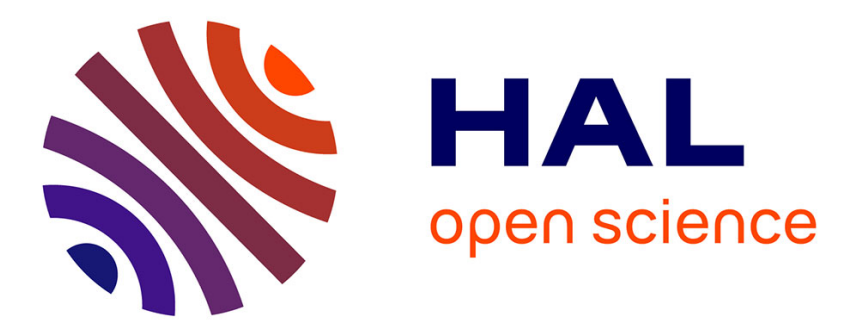

\title{
An experimental investigation of the determinants and consequences of self-handicapping strategies across motivational climates
}

Guillaume R. Coudevylle, Kathleen Martin Ginis, Jean-Pierre Famose, Christophe Gernigon

\section{To cite this version:}

Guillaume R. Coudevylle, Kathleen Martin Ginis, Jean-Pierre Famose, Christophe Gernigon. An experimental investigation of the determinants and consequences of self-handicapping strategies across motivational climates. European Journal of Sport Science, 2009, 9 (4), pp.219-227. 10.1080/17461390902780437. hal-01343256

\section{HAL Id: hal-01343256 \\ https://hal.univ-antilles.fr/hal-01343256}

Submitted on 8 Jan 2018

HAL is a multi-disciplinary open access archive for the deposit and dissemination of scientific research documents, whether they are published or not. The documents may come from teaching and research institutions in France or abroad, or from public or private research centers.
L'archive ouverte pluridisciplinaire HAL, est destinée au dépôt et à la diffusion de documents scientifiques de niveau recherche, publiés ou non, émanant des établissements d'enseignement et de recherche français ou étrangers, des laboratoires publics ou privés. 
1 Running head: SELF-HANDICAPPING AND MOTIVATIONAL CLIMATE

2

3

10

\section{An Experimental Investigation of Determinants and Consequences of Self-Handicapping Strategies Across Motivational Climates}

Guillaume R. Coudevylle

McMaster University

Department of Kinesiology

Hamilton, Ontario,

L8S 4K1

Canada

Tel : (905) 525-9140 Ext. 23574

e-mail : coudevg@mcmaster.ca or guillaumecoudevylle@hotmail.com

Kathleen A. Martin Ginis

McMaster University

Department of Kinesiology

Jean-Pierre Famose

Université de Pau et des Pays de l'Adour,

Département STAPS

Christophe Gernigon

Université de Montpellier 1

UFR STAPS 


\section{Abstract}

2 The purpose of the present experiment was to examine whether the use of claimed and behavioral

3 self-handicaps and their correlates differed across experimentally manipulated motivational

4 climates. Fifty-six competitive basketball players participated in the study. A cross over design

5 was utilized, such that all participants completed the experimental task (i.e., a test of basketball

6 skill) in both mastery and performance climates. ANOVAs showed that claimed self-handicaps

7 were used more in the performance than the mastery condition but only for the men. In addition,

8 greater behavioral self-handicapping occurred in the performance than the mastery climate.

9 Contrary to expectation, neither type of self-handicap was related to performance on the

10 basketball task in either climate. These findings reinforce the conceptual distinction between

11 claimed and behavioral self-handicaps and suggest that individual and environmental factors may

12 differentially influence each type of handicap.

15 Key words: claims, behaviors, performance, basketball 
An Experimental Investigation of Determinants and Consequences of Self-handicapping Strategies Across Motivational Climates

phenomenon as "any action or choice of performance setting that enhances the opportunity to externalize (or excuse) failure and to internalize (reasonably accept credit for) success" (p. 406).

Self-handicapping involves making claims or engaging in behaviors prior to an evaluated performance, in order to excuse a possible failure or to make a success more gratifying (Leary \& Shepperd, 1986). For example, some people may consume alcohol to avoid the impact of negative feedback for failure and to enhance the repercussions of positive feedback for success (Jones \& Berglas, 1978). Other people may get too little sleep before an exam or exaggerate the effects of illness or injury (see Berglas \& Jones, 1978).

Jones and Berglas (1978) indicated that self-handicappers are legion in the sports world.

As such, the study of self-handicapping may be particularly pertinent within the physical activity domain. Field studies and controlled experiments have been used to examine factors associated with the use of self-handicaps prior to competitive or evaluated physical activity events (for a review, see Martin Ginis, Lindwall, \& Prapavessis, 2007; Prapavessis, Grove, \& Eklund, 2004). These factors include lower self-efficacy and self-esteem (Martin \& Brawley, 2002), publicimages on important ability-based dimensions (Kolditz \& Arkin, 1982; Self, 1990), high perceived event importance (e.g., Rhodewalt, Saltzman, \& Wittmer, 1984), elevated competitive state anxiety (Prapavessis \& Grove, 1994; Ryska, Yin, \& Cooley, 1998), and performanceavoidance goals (e.g., Elliot, Cury, Fryer, \& Huguet, 2006). More recently, a couple of studies have demonstrated that the motivational climate can also influence self-handicapping (Kuczka \& Treasure, 2005; Standage, Treasure, Hooper, \& Kuczka, 2007). 
The concept of motivational climate (Ames, 1992) is derived from achievement goal

2 theory (AGT, Ames, 1984; Dweck, 1986; Nicholls, 1989) and refers to the saliency of mastery

3 (task) and performance (ego) cues in an achievement setting. According to AGT, the

4 demonstration of ability is the goal of action in achievement settings. In a performance-oriented

5 motivational climate, success is defined in terms of out-performing others, and performance

6 evaluations are based on social comparisons. In contrast, in a mastery-oriented motivational

7 climate, success is defined as mastering a task, and evaluations of one's performance are self-

8 referenced (Ames \& Archer, 1988).

9 Several studies have utilized an achievement goal perspective to try to better understand

10 self-handicapping. Most of these studies have focused on the role of participants' personal

11 achievement goals as they relate to self-handicapping in academic (e.g., Midgley \& Urdan, 2001;

12 Urdan, 2004) or physical education domains (e.g., Elliot et al., 2006; Ommundsen, 2001, 2004).

13 For example, in a sample of adolescent physical education students, Elliot and colleagues

14 analysed personal achievement goals using a trichotomous framework (i.e., mastery-approach,

15 performance-approach, and performance-avoidance). They demonstrated that performance-

16 avoidance goals evoked more behavioral and self-reported self-handicapping than performance-

17 approach and mastery goals.

18 In one of the few studies to utilize an achievement goal perspective within the context of

19 competitive sport, Kuczka and Treasure (2005) found that among elite golfers, the use of claimed

20 self-handicaps prior to a tournament was negatively correlated with perceptions of the team

21 climate as being mastery-oriented. That is, athletes who perceived their team environment to be

22 higher in mastery cues (e.g., a focus on self-referenced performance) used fewer self-handicaps

23 than those who perceived the environment to be lower in mastery-involving cues. In contrast, a

24 weak positive correlation was found between claimed self-handicapping and perceptions of the 
1 team climate as being performance-oriented. Thus, golfers who perceived more performance-

2 oriented cues in the team environment (e.g., a focus on social comparisons and out-performing

3 others) used more self-handicaps than golfers who perceived fewer of these cues. The results of

4 this study suggest that motivational climate may influence the use of self-handicaps. However,

5 given the non-experimental study design it was not possible to determine if the actual use of self-

6 handicaps differed as a function of motivational climates.

7 To date, only one published study has experimentally manipulated motivational climates

8 and examined the effects on self-handicapping (Standage et al., 2007). Standage and colleagues

9 found that within the context of a physical education class, students reported more self-handicaps

10 prior to performing an endurance-running task in a performance-oriented climate than in a task-

11 oriented climate. The authors concluded that students exposed to performance-involving cues

12 become preoccupied with their comparative ability (i.e., appearing able or not appearing unable),

13 thus making self-handicapping more likely as a self-protective strategy to deflect attention away

14 from a lack of ability (Midgley \& Urdan, 2001; Urdan \& Midgley, 2001).

15 Taken together, the Kuczka and Treasure (2005) and Standage and colleagues (2007)

16 studies suggest that the motivational climate can influence self-handicapping. However, a key

17 limitation of these studies has been an exclusive focus on claimed self-handicapping. There has

18 been little consideration as to whether different motivational climates differentially elicit claimed

19 versus behavioral self-handicaps. Behavioral handicaps refer to deliberate, overt acts that would

20 make success on a task more difficult such as ingesting drugs or alcohol, withholding effort, and

21 choosing to perform in suboptimal conditions. Conversely, claimed handicaps are verbal claims

22 about performance impediments such as being injured, ill, socially anxious, in a bad mood or a

23 victim of traumatic life events (for a review, see Martin Ginis et al., 2007; Prapavessis et al.,

24 2004). Theorists have highlighted the important conceptual distinction between the two types of 
1 self-handicaps (e.g., Hirt, Deppe, \& Gordon, 1991; Leary \& Shepperd, 1986), but effort has not

2 been directed toward identifying whether they have different determinants. With this shortcoming

3 in mind, the primary purpose of the present experiment was to examine whether the use of

4 claimed and behavioral self-handicaps differ across experimentally manipulated motivational

5 climates.

6 We predicted that claimed and behavioral self-handicaps would be used more in the

7 performance than mastery condition. Our predictions regarding claimed self-handicaps were

8 based on findings from previous sport and motivational climate research. Specifically, Kuczka

9 and Treasure (2005) showed that the use of claimed self-handicaps were positively correlated

10 with perceptions of a performance climate. Likewise, Standage and his colleagues (2007) found

11 that claimed self-handicaps were more important in a performance climate than a mastery

12 climate. Our predictions regarding behavioral self-handicaps were based on what is known about

13 the nature of behavioral self-handicaps and the motives of people who use them. That is, the

14 behavioral self-handicapper aims to influence an audience's impressions by providing a credible

15 excuse for possible failure (e.g., Schlenker, Pontari, \& Christoper, 2001; Snyder, 1990). As the

16 credibility of a self-handicap hinges on it being observable and verifiable (Hirt et al., 1991),

17 situations involving social comparisons and an audience (i.e., performance-oriented climates)

18 should prompt athletes to use the more convincing, albeit more detrimental, form of self-handicap

19 (i.e., behavioral self-handicaps) to protect or enhance their public image. In contrast, athletes

20 should be less likely to risk disrupting their performance by using behavioral self-handicaps in a

21 mastery climate where social comparisons and audience evaluations are downplayed.

22 A secondary purpose was to examine the effects of each type of self-handicap on athletic

23 performance and to determine if these effects vary between performance and mastery climates.

24 Studies examining the effects of self-handicapping on performance have produced inconsistent 
1 results. Some studies have indicated that participants who used a situational self-handicapped

2 performed better than those who did not (e.g., Sanna \& Mark, 1995), whereas other studies

3 showed that individuals who scored highly on a measure of trait self-handicapping performed less

4 well academically (e.g., Zuckerman, Kieffer \& Knee, 1998). One possible explanation for these

5 inconsistent results is that the actual, situational use of self-handicaps improves performance

6 because the self-handicapper obtains the advantage of anxiety reduction (Leary \& Shepperd,

7 1986). On the other hand, chronic use of self-handicaps can decrease competence and

8 consequently, performance. Clearly, further research is needed to determine the effects of the

9 situational use of self-handicaps on performance.

10 In addition, the effects on performance are probably different depending on whether an

11 athlete uses a claimed self-handicap--such as claiming to be sick or tired--or a behavioral self-

12 handicap, such as reducing preparatory effort. Indeed, simply claiming to be too tired serves as an

13 excuse for poor performance, but does not actually reduce the likelihood of success. In contrast,

14 not practicing can also provide an excuse for poor performance, but also decreases the likelihood

15 of a successful performance (see Hirt et al., 1991). Only one published study has examined the

16 effects of both behavioral and claimed self-handicaps on athletic performance (Elliot et al.,

17 2006). This study found that both types of self-handicaps had detrimental effects on performance.

18 However, in contrast, Coudevylle, Martin Ginis, and Famose (2008a) showed that performance

19 on a basketball task was negatively related to behavioral self-handicapping, but was not related to

20 claimed self-handicapping. Another study looked only at claimed self-handicaps and found that

21 claimed self-handicapping had a positive impact on running performance among children in a

22 physical education class who had relatively low self-confidence (Ryska, 2002). Given these

23 equivocal findings, further examination of the issue is warranted. Consistent with the notion that

24 behavioral self-handicaps are, by definition, more detrimental than claimed self-handicaps (Hirt 
1 et al., 1991), it was predicted that behavioral self-handicaps would have a significant negative

2 effect on performance and the use of claimed self-handicaps would be unrelated to performance

3 in the both climates.

Method

5 Participants

Fifty-six competitive basketball players, 25 men $(M$ age $=20.7$ years, $S D=2.6)$ and 31

7 women $(M$ age $=20.8$ years, $S D=3.9)$, participated in the study. All players competed at the

8 French regional or national levels. Participants were recruited from eight different teams.

9 Design and Overview of Procedure

10 A cross over design was utilized, such that all participants completed the experimental

11 task in both a mastery and a performance climate. The order of presentation of the climates was

12 randomly assigned by lottery, and the two tests were conducted one week apart. To minimize the

13 possibility of athletes using scheduling problems or discomfort with the testing environment as

14 self-handicaps, the experiment was conducted in the athletes' usual training hall and during a

15 regularly scheduled training session.

16 Measures

17 Claimed Self-handicapping. A state measure equivalent to that used by Martin and Brawley

18 (study 2, 2002) was used to measure claimed self-handicapping. Yet whereas Martin and

19 Brawley's scale consisted of just 7 possible impediments, our scale consisted of 13 impediments

20 that athletes may use as self-handicaps such as: "I am feeling tired," "I have personal concerns in

21 this moment," "I am not feeling well mentally," "I am not sufficiently prepared for the test," "I am

22 feeling well," and "I am approaching the test under the best conditions." (Note that the last two

23 items were reverse-scored.) The impediments were those most frequently cited by athletes in

24 Carron and colleagues' studies of self-handicapping in sport (Carron, Prapavessis, \& Grove, 
1 1994; Hausenblas \& Carron, 1996). In addition, participants were presented with a fourteenth,

2 open-ended item that gave the opportunity to list any other potential impediments to their

3 performance. For each item, participants indicated (a) whether the impediment was present

4 (yes/no), and (b) the extent to which each impediment would interfere with their performance

5 (i.e., perceived impact), using a scale ranging from 0 (not at all) to 6 (extremely). The number of

6 claimed self-handicaps was computed. The claimed impact was calculated by considering the

7 items to which the participants had answered "yes" and by adding the impact scores for these

8 items. Higher scores were indicative of greater claims of performance impediments, and as such,

9 greater self-handicapping. This is the same measure as reported in Coudevylle, Martin Ginis,

10 Famose, and Gernigon (2008b).

11 With regard to the psychometric properties of the scale, studies have provided construct

12 validity for this approach to measuring self-handicapping by demonstrating significant

13 correlations between the claimed impact of performance impediments and theoretically

14 meaningful constructs such as self-presentational efficacy (Martin \& Brawley, 2002), self-

15 esteem, and performance self-efficacy (Coudevylle et al., 2008a; Martin \& Brawley, 2002).

16 Internal consistency is not an appropriate psychometric index for this type of self-handicapping

17 measure because athletes are not expected to respond similarly to all of the scale items. Indeed,

18 when athletes use claimed self-handicaps, they cite only one or two performance impediments. It

19 is unusual for an athlete to cite several claimed self-handicaps, probably because only a single

20 self-handicapping claim is needed to protect an athlete's image, and the use of multiple self-

21 handicaps could have considerable self-presentational liabilities.

22 Behavioral Self-handicapping. According to Prapavessis and colleagues (2004), a lack of

23 preparatory effort preceding a test constitutes an index of behavioral self-handicapping within the

24 context of sports participation. Thus, for the purpose of the present experiment, behavioral self- 
1 handicapping was operationalized as the number of preparatory shots taken during a warm-up

2 period immediately prior to the experimental task. A short practice time has been identified as a

3 self-handicapping strategy in previous studies because it is detrimental to performance (see

4 Harris \& Snyder, 1986; Tice, 1991). Furthermore, as none of the participants had previous

5 experience with the experimental task, it was reasonable to expect that all participants should

6 desire at least some practice time.

7 The validity of practice time and effort as an index of behavioral self-handicapping has

8 been demonstrated in several studies. For instance, a couple of studies have shown that the

9 amount of time spent warming up/practicing is related to self-handicapping (e.g., Deppe \&

10 Harackiewicz, 1996; Tice \& Baumeister, 1990). In addition, Rhodewalt and colleagues (1984)

11 showed that swimmers who scored high on a trait measure of self-handicapping were more likely

12 to withhold practice effort prior to competitions compared to swimmers who scored low on trait

13 self-handicapping.

14 Performance. Performance was scored by counting the number of successful shots and passes

15 through an obstacle course (described next). Performance scores could range from 0 to 11 .

16 Manipulation Check. Given that athletes experience greater sport competition anxiety in

17 performance than mastery climates (Thill \& Cury, 2000), a French version of the Competitive

18 State Anxiety Inventory - 2 (CSAI-2; Martens et al., 1990) -- l'Echelle d'Etat d'Anxiété à la

19 Compétition (EEAC; Cury, Sarrazin, Peres, \& Famose, 1999) was administered in order to

20 determine the veracity of our experimental manipulations. The EEAC is reliable and valid for use

21 with French athletes. It consists of 7-items measuring cognitive anxiety and 7-items measuring

22 somatic anxiety. For each item, participants indicated the extent to which they were currently

23 experiencing each anxiety symptom, using a Likert scale ranging from 1 (not at all) to 4

24 (completely). 
The Experimental Task.

An individual test of basketball skill was designed in consultation with a committee of national level basketball experts. The task consisted of completing three repetitions of an obstacle course laid out on a standard basketball court. The test began with the completion of two freethrows followed by running to mid-court, and then turning around backwards and performing a backward defensive shuffle to the end of the court. Then, the participant picked up a basketball and dribbled it to mid-court. At mid-court, the participant dribbled the ball between three pylons, while dribbling the ball between their legs and behind the back. The participant then continued to the basket and attempted a lay-up. After the lay-up, the participant repeated the entire course again and finished with a jump shot. The course was repeated a third time, finishing with a threepoint shot. This is the same task as reported in Coudevylle and colleagues (2008a, 2008b). Procedure

Recent experimental research on self-handicapping and motivational climate has included a public demonstration component along with a normative comparison component in order to create a performance-based environment (e.g., Cury, Da Fonseca, Rufo, Peres, \& Sarrazin, 2003; Elliot et al., 2006). Indeed, many authors in the achievement goal literature contend that both components are integral to performance-based goals and, therefore, must be included in manipulations of performance-based goal constructs (Ames, 1992). In accordance with these studies, the mastery climate condition was conducted in private while the performance climate condition was conducted in public.

Performance Climate Testing Conditions. To create a performance climate, the testing situation emphasized results, comparisons of one's own performance relative to others, normative comparisons, public awareness of the use of self-handicaps and a public performance (Ames \& Archer, 1988; see Elliot et al., 2006). Specifically, each participant performed the test in the 
1 presence of spectators, coaches and other players, participants were told that their test results

2 would be used to identify the best and worst players in the region, and their results would be

3 compared with their teammates' results.

4 After hearing and reading about the conditions in which the test would be performed,

5 participants completed the manipulation check (i.e., measure of anxiety). Then, they completed

6 the measure of claimed self-handicapping. In order to mask the true purpose of the self-

7 handicapping questionnaire, participants were told:

8 "The following questionnaire is intended to know your general actual state in order to

9 comment on your results today. It will allow those that will evaluate your competence (the

10 experimenter, your trainer, the other players, the spectators) to consider your current personal

11 situation when authenticating your results and comparing them with those of the other

12 participants. Your responses to this questionnaire will be made public along with your results

13 so that those who evaluate your performance will be better able to evaluate your competence."

14 After completing the claimed self-handicapping measure, the experimenter explained (orally and

15 through written instructions) the warm-up procedure. Specifically, participants were told that they

16 could have as many practice shots as they desired to warm-up. To make sure that all participants

17 realized that the number of preparatory shots could serve as a behavioral self-handicap, the

18 experimenter indicated that the number of preparatory shots could provide an explanation for a

19 good or bad performance on the test. He also reminded players that a good warm-up is essential

20 to a good performance. Therefore, participants knew that the lack of practice before the test could

21 be detrimental to their performance (see Harris \& Snyder, 1986; Tice, 1991). This was a

22 reasonable claim, given that no participant had previous experience with the experimental task.

23 As no participant had previously performed the experimental task, one can assume that a warm-

24 up would be essential to successful performance of the task. Participants then warmed-up in two 
1 periods. The first warm-up period (15 minutes) consisted of a quick run, stretching and

2 repetitions of the course, but without taking any practice shots. The second warm-up period

3 consisted of taking practice shots. Although participants performed the experiment in groups,

4 they warmed up individually (i.e., no other players were on the court at the same time, but other

5 players were present as observers). The experimenter counted the number of preparatory shots

6 taken as the measure of behavioral self-handicapping. Once the player indicated to the

7 experimenter that she/he was finished warming up, the basketball test proceeded.

8 Mastery Climate Testing Conditions. To create a mastery climate, the testing situation

9 emphasized private performance, success was defined as mastering a task, and evaluations of

10 one's performance were self-referenced (Ames \& Archer, 1988). Focus of attention was on the

11 process of learning, the importance of results was downplayed, results were kept confidential,

12 and only the experimenter and the participant were aware of the participant's use of self-

13 handicaps. Specifically, the participants were told that the purpose of the experiment was to

14 provide an opportunity to improve their level of play, by identifying their strong and weak points

15 and providing useful information on their technical abilities. It was explained that their results

16 would not be made public (i.e., coach and teammates would not know their results), nor would

17 comparisons be made between their scores and other teammates or players from other clubs.

18 Participants then completed the manipulation check and the measure of claimed self-

19 handicapping was introduced. Participants were told that the questionnaire was confidential and

20 that nobody other than the experimenter, would see their responses.

21 After completing the self-handicapping measure, the warm-up procedure was explained.

22 In accord with Kolditz and Arkin (1982), the warm-up was conducted in private condition.

23 Therefore, the experimenter counted the number of shots taken without the knowledge of the 
1 participant. Once the player indicated to the experimenter that she/he was finished warming up,

2 the experimental task proceeded.

Once the participant had completed the task in both experimental conditions (i.e., mastery

4 and performance), the participant was debriefed regarding the true purpose of the study.

5 Additionally, the first author provided each team with a lecture and proposed a discussion on

6 self-handicapping and its consequences.

Results

Manipulation Check

9 In order to assess the adequacy of the motivational climate manipulation, anxiety levels

10 were compared across the two conditions. Consistent with previous motivational climate

11 research, athletes experienced greater anxiety in the performance than mastery climate (Thill \&

12 Cury, 2000). Indeed, a one-way repeated measures ANOVA indicated that participants reported

13 greater cognitive anxiety in the performance $(M=13.9, S D=4.2)$ than mastery conditions $(M=$

$1412.4, S D=3.9), F(1,55)=6.73, p<.05$. With regard to somatic anxiety, participants tended to

15 report greater somatic anxiety in the performance $(M=11.37, S D=2.9)$ than mastery conditions

$16(M=10.57, S D=2.68), F(1,55)=3.38, p=.07$. Based on these results, we were satisfied that

17 different motivational climates had been created and we continued with our hypothesis tests.

18 Motivational Climate as a Determinant of Self-handicapping

19 The first set of analyses determined if the use of self-handicapping strategies (i.e., claimed

20 and behavioral) varied between performance and mastery climates. Because previous research

21 suggests that participants' sex should be controlled for in such analyses (e.g., Elliot et al., 2006;

22 Kuczka \& Treasure, 2005), sex was treated as an independent variable. Separate $2(\operatorname{sex}) \times 2$

23 (motivational climate) ANOVAs were conducted on the measures of claimed and behavioral self-

24 handicaps. The ANOVA for number of claimed self-handicaps showed no main effects for sex, 
1 nor motivational climate (all $p s>.05)$, but showed a significant sex $\times$ climate interaction $[F(1$,

$254)=4.43, p<.05]$. The ANOVA for impact of claimed self-handicaps showed no main effects

3 for sex, nor motivational climate, and no interaction effects (all $p s>.05$ ). With regard to

4 behavioral self-handicapping, the ANOVA showed a main effect for $\operatorname{sex}[F(1,54)=5.44, p<$

$5.05]$ and a main effect for climate $[F(1,54)=46.21, p<.001]$ but no sex $\times$ climate interaction $(p$

$6>.05)$. Table 1 presents the means and standard deviations for the measures of self-handicapping

7 as a function of sex and motivational climate. Inspection of these means indicates that men used

8 claimed handicaps more in the performance climate than in the mastery climate, whereas women

9 used claims similarly in both climates. In addition, both men and women took fewer preparatory

10 shots (i.e., engaged in more behavioral self-handicapping) in the performance climate than the

11 mastery climate.

12 Consequences of Self-handicapping Strategies on Performance

13 The second set of analyses examined the effects of self-handicapping (i.e., claimed and

14 behavioral) on performance and determined if these relationships varied between performance

15 and mastery climates. Contrary to our hypotheses, correlational analyses showed that

16 performance (see Table 2 and Table 3) was not associated with claimed or behavioral self-

17 handicapping in either the performance or mastery climates $(p s>.05)$.

\section{Discussion}

\section{Motivational Climate as a Determinant of Self-handicapping}

The primary purpose of the present experiment was to examine whether motivational

21 climate differentially influenced claimed and behavioral self-handicapping. Specifically, the first

22 objective was to determine if the use of self-handicapping strategies (i.e., claimed vs. behavioral)

23 varied between performance and mastery climates. Overall, the present research provided partial

24 support for our hypotheses. Both male and female athletes used greater behavioral self- 
1 handicapping in the performance than mastery climate. Although male athletes used more

2 claimed self-handicaps in the performance climate than the mastery climate, there were no

3 differences in the impact of claimed self-handicaps for either men or women. The observed

4 differences in self-handicapping across the climates suggest that self-handicaps are used in order

5 to provide audiences with viable and credible explanations for a poor performance. In all logic,

6 athletes performing in private situations would not elect to reduce their effort, or make excuses,

7 as a self-handicapping strategy. However, they will self-handicap when they are being observed,

8 particularly in a public performance climate situation.

9 Interestingly, the differential effects of motivational climate on claimed self-handicapping

10 were evident only for the male study participants. Women may use claimed self-handicaps

11 equally across performance and mastery climates in order to reassure themselves about their

12 ability. Furthermore, contrary to our expectations, the results concerning claimed impact were not

13 statistically significant. It appears that behavioral self-handicapping is a strategy more efficient

14 than claimed self-handicap to excuse a possible failure or to make a success more gratifying.

15 Our results also suggest that performance climates are an ideal context in which to study

16 self-handicapping. An experiment conducted in a performance climate (i.e., test in public,

17 evaluation centred on the results, social comparison, results made public) is more likely to

18 produce an environment threatening to the public-self and thus, to elicit self-handicapping,

19 compared to an experiment conducted in a mastery climate (i.e., private test centred on the

20 mastery of execution, temporal comparison, confidentiality of results).

21 Consequences of Self-handicapping Strategies on Performance

22 A secondary purpose of our experiment was to examine the effects of self-handicapping

23 (i.e., claimed and behavioral) on athletic performance and to determine if these effects vary

24 between performance and mastery climates. The present research provided support for our 
1 hypothesis that the use of claimed self-handicaps would not affect performance. These results are

2 consistent with previous studies (Coudevylle et al., 2008a; Hirt et al., 1991) which have shown

3 that simply claiming performance impediments does not have any subsequent effects on

4 performance. However, contrary to our hypothesis, we did not observe any negative effects of

5 behavioral self-handicapping on performance in either the performance or the mastery climates.

6 The null effects of behavioral self-handicapping are contrary to the findings of Elliot and

7 colleagues (2006) who showed that reduced preparatory effort (i.e., a behavioral self-handicap)

8 was linked with poorer performance. Our findings are also contrary to theorizing regarding the

9 detrimental effects of behavioral self-handicaps (Leary \& Shepherd, 1986).

10 There are at least two possible explanations for why we did not find a negative

11 relationship between behavioral self-handicapping and performance. First, Coudevylle and

12 colleagues (2008b) showed that participants who engaged in more behavioral self-handicapping

13 (i.e., took fewer preparatory shots), reported greater increases in perceptions of cognitive anxiety

14 as facilitating their performance. It could be that reduced anxiety serves as a mediator between

15 behavioral self-handicapping and performance. Reducing preparation is likely detrimental to

16 performance, but at same time, this reduction offers protection by generating a decrease of

17 anxiety, which is favourable to performance. In fact, the advantage gained by reducing anxiety

18 likely compensates for the detrimental effect of behavioral self-handicapping and thus, does not

19 allow us to see any effects on performance. This null finding could be also due to the

20 heterogeneous athletic ability of the participants. If participants using a low number of

21 preparatory shots were more skilled than those that use a greater number of preparatory shots,

22 then differences in ability would confound the relationship between behavioral self-handicapping

23 and performance. In future research, skill level of the participants should be controlled in order to

24 gain a better understanding of the effects of self-handicapping on sporting performance. 
Theorists have highlighted the important conceptual distinction between claimed and

3 behavioral self-handicaps (e.g., Hirt et al., 1991; Leary \& Shepperd, 1986). However, there has

4 been virtually no research examining whether the two types of handicaps have different

5 predictors. The present study provides preliminary data to reinforce the conceptual distinction

6 between claimed and behavioral self-handicaps suggesting that environmental factors may

7 differentially influence each type of handicap. Taken together, the present findings indicated that

8 only behavioral self-handicap is predicted by a performance climate environment. From an

9 applied perspective, coaches, sport psychologists, and other interventionists should promote

10 mastery climates whenever possible, even in competition through mental skills training (e.g.,

11 goal-setting, mental imagery), in order to decrease the possibility of behavioral self-

12 handicapping. Although we did not find detrimental effects of behavioral self-handicapping in the

13 present study, it is possible that future investigations that control for athletes' skill level through

14 careful pre-testing, will find that behavioral self-handicapping is damaging to sports performance. 


\section{References}

2 Ames, C. A. (1984). Achievement attributions and self-instructions in competitive and individualistic goal structures. Journal of Educational Psychology, 76, 478-487.

4 Ames, C. A. (1992). Achievement goals, motivational climate, and motivational processes. In G. Kinetics Publishers.

Ames, C. A., \& Archer, J. (1988). Achievement goals in the classroom: Students' learning strategies and motivation processes. Journal of Educational Psychology, 80, 260-267.

9 Berglas, S., \& Jones, E. E. (1978). Drug choice as a self-handicapping strategy in response to non contingent success. Journal of Personality and Social Psychology, 36, 405-417.

11 Carron, A. V., Prapavessis, H., \& Grove, J. R. (1994). Group effects and self-handicapping. Journal of Sport \& Exercise Psychology, 16, 246-257.

13 Coudevylle, G., Martin Ginis, K., \& Famose, J-P. (2008a). Determinants of self-handicapping strategies in sport and their effects on athletic performance. Social Behavior and Personality, 36, 391-398.

16 Coudevylle, G., Martin Ginis, K., Famose, J-P., \& Gernigon, C. (2008b). Effects of selfhandicapping strategies on anxiety prior to athletic performance. The Sport Psychologist, $22,304-315$.

Cury, F., Da Fonseca, D., Rufo, M., Peres, C., \& Sarrazin, P. (2003). The trichotomous model and investment in learning to prepare for a sport test: A mediational analysis. British Journal of Educational Psychology, 73, 529-543.

22 Cury, F., Sarrazin, P., Peres, C., \& Famose, J-P. (1999). Mesurer l'anxiété du sportif en compétition : présentation de l'échelle d'état d'anxiété en compétition (EEAC). In Ch. Le 
1 Deppe, R. K., \& Harackiewicz, J. M. (1996). Self-handicapping and intrinsic motivation: Buffering intrinsic motivation from the threat of failure. Journal of Personality and Social Psychology, 70, 868-876.

Dweck, C. S. (1986). Motivational processes affecting learning. American Psychologist, 41, 1040-1048.

Elliot, A. J., Cury, F., Fryer, J. W., \& Huguet, P. (2006). Achievement goals, self-handicapping, and performance attainment: A mediational analysis. Journal of Sport \& Exercise Psychology, 28, 344-361.

Harris, R. N., \& Snyder, C. R. (1986). The role of uncertain self-esteem in self-handicapping. Journal of Personality and Social Psychology, 51, 451-458.

Hausenblas, H. A., \& Carron, A. V. (1996). Group cohesion and self-handicapping in female and male athletes. Journal of Sport and Exercise Psychology, 18, 132-143.

Hirt, E. R., Deppe, R. K., \& Gordon, L. J. (1991). Self-reported versus behavioral selfhandicapping: Empirical evidence for a theoretical distinction. Journal of Personality and Social Psychology, 61, 981-991.

Jones, E. E., \& Berglas, S. (1978). Control of attributions about the self through selfhandicapping strategies: The appeal of alcohol and the role of underachievement. Personality and Social Psychology Bulletin, 4, 200-206.

Kolditz, T. A., \& Arkin, R. M. (1982). An impression management interpretation of the selfhandicapping strategy. Journal of Personality and Social Psychology, 43, 492-502.

Kuczka, K. K., \& Treasure, D. C. (2005). Self-handicapping in competitive sport: Influence of the motivational climate, self-efficacy, and perceived importance. Psychology of Sport and Exercise, 6, 539-550. 
1 Leary, M. R., \& Shepperd, J. A. (1986). Behavioral self-handicapping vs. self-reported handicaps: A conceptual note. Journal of Personality and Social Psychology, 51, 12651268.

4 Martens, R., Vealey, R. S., \& Burton, D. (1990). Competitive anxiety in sport. Champaign, IL: Human Kinetics Publishers.

6 Martin, K. A., \& Brawley, L. R. (2002). Self-handicapping in physical achievement settings: The 7 contributions of self-esteem and self-efficacy. Self and Identity, 1, 337-351.

8 Martin Ginis, K. A., Lindwall, M., \& Prapavessis, H. (2007). Who care what other people think?

9 Self-presentation in exercise and sport. In G. Tenenbaum \& R. Eklund (Eds.), Handbook 10 of Sport Psychology, 3rd ed. (pp. 136-159). Wiley publishers.

11 Midgley, C., \& Urdan, T. (2001). Academic self-handicapping and achievement goals: A further 12 examination. Contemporary Educational Psychology, 26, 61-75.

13 Nicholls, J. (1989). The competitive ethos and democratic education. Cambridge, MA: Harvard $14 \quad$ University Press.

15 Ommundsen, Y. (2001). Self-handicapping strategies in physical education classes: The influence of implicit theories of the nature of ability and achievement goal orientations. Psychology of Sport and Exercise, 2, 139-156.

18 Ommundsen, Y. (2004). Self-handicapping related to task and performance-approach and avoidance goals in physical education. Journal of Applied Sport Psychology, 16, 183-197.

20 Prapavessis, H., \& Grove, J. R. (1994). Personality variables as antecedents of precompetitive mood state temporal patterning. International Journal of Sport Psychology, 25, 347-365.

22 Prapavessis, H., Grove, J. R., \& Eklund, R. C. (2004). Self-presentational issues in competition and sport. Journal of Applied Sport Psychology, 16, 19-40. 
1 Rhodewalt, F., Saltzman, A. T., \& Wittmer, J. (1984). Self-handicapping among competitive athletes: The role of practice in self-esteem protection. Basic and Applied Social Psychology, 5, 197-209.

4 Ryska, T. A. (2002). Effects of situational self-handicapping and state self-confidence on the physical performance of young participants. The Psychological Record, 52, 461-478.

Ryska, T. A., Yin, Z. N., \& Cooley, D. (1998). Effects of trait and situational self-handicapping on competitive anxiety among athletes. Current Psychology, 17, 48-56.

Sanna, L. J., \& Mark, M. M. (1995). Self-handicapping expected evaluation, and performance: Accentuating the positive and attenuating the negative. Organizational Behavior and Human Decision Processes, 64, 84-102.

11 Schlenker, B. R., Pontari, B. A., \& Christoper, A. N. (2001). Excuses and character: Personal and social implications of excuses. Personality and Social Psychology Review, 5, 15-32.

13 Self, E. A. (1990). Situational influences on self-handicapping. In R. L. Higgins, C. R. Snyder et S. Berglas (Eds.), Self-handicapping: The paradox that isn't? (pp. 37-68). New York: Plenum Press.

Snyder, C. R., \& Smith, T. W. (1982). Symptoms as self-handicapping strategies: The virtues of old wine in a new bottle. In G. Weary (Eds.), Integrations of Clinical and Social Psychology (pp. 104-127). New York: Oxford University Press.

22 Standage, M., Treasure, D. C., Hooper, K., \& Kuczka, K. (2007). Self-handicapping in school physical education: The influence of the motivational climate. British Journal of Educational Psychology, 77, 81-99. 
1 Thill, E., \& Cury, F. (2000). Learning to play golf under-different goal conditions: Their effects on irrelevant thoughts and on subsequent control strategies. European Journal of Social Psychology, 30, 101-122.

4 Tice, D. M. (1991). Esteem protection or enhancement? Self-handicapping motives and attributions differ by trait self-esteem. Journal of Personality and Social Psychology, 60, 711-725.

7 Tice, D. M., \& Baumeister, R. F. (1990). Self-esteem, self-handicapping, and self-presentation: The strategy of inadequate practice. Journal of Personality 58, 443-464.

9 Urdan, T. (2004). Predictors of academic self-handicapping and achievement: Examining achievement goals, classroom goals structures, and culture. Journal of Educational Psychology, 96, 251-264.

12 Urdan, T., \& Midgley, C. (2001). Academic self-handicapping: What we know, what more there is to learn. Educational Psychology Review, 13, 115-138.

14 Zuckerman, M., Kieffer, S. C., \& Knee, C. R. (1998). Consequences of self-handicapping:

15 Effects on coping, academic performance, and adjustment. Journal of Personality and $16 \quad$ Social Psychology, 74, 1619-1628. 
Author note

2 We extend our appreciation to Martyn Standage for his comments on a previous version of this

3 manuscript.

4 
Table 1.

2 Descriptive Statistics for Self-handicapping and Performance across the Motivational Climates

3

\begin{tabular}{|c|c|c|c|c|c|c|c|c|}
\hline & \multicolumn{2}{|c|}{$\begin{array}{c}\text { Claimed } \\
\text { Self-handicapping }\end{array}$} & \multicolumn{2}{|c|}{$\begin{array}{l}\text { Claimed } \\
\text { Impact }\end{array}$} & \multicolumn{2}{|c|}{$\begin{array}{c}\text { Behavioral } \\
\text { Self-handicapping }\end{array}$} & \multicolumn{2}{|c|}{ Performance } \\
\hline & $M$ & $S D$ & $M$ & $S D$ & $M$ & $S D$ & $M$ & $S D$ \\
\hline & & & & & & & & \\
\hline Performance Climate & 4.28 & 2.34 & 15.33 & 7.53 & \multicolumn{2}{|c|}{$17.94 * * * 12.59$} & $6.73^{\mu}$ & 1.50 \\
\hline Men & $4.56^{a}$ & 2.21 & 16.24 & 7.13 & $21.00^{+}$ & 16.30 & 6.68 & 1.43 \\
\hline Women & 4.06 & 2.44 & 14.61 & 7.89 & $15.48^{+}$ & 7.99 & 6.77 & 1.58 \\
\hline & & & & & & & & \\
\hline Mastery Climate & 3.91 & 2.53 & 13.96 & 8.14 & \multicolumn{2}{|c|}{$29.82 * * * 18.03$} & $7.30^{\mu}$ & 1.89 \\
\hline Men & $3.52^{\alpha}$ & 2.40 & 13.24 & 8.08 & $36.12^{+}$ & 22.54 & 7.16 & 1.95 \\
\hline Women & 4.22 & 2.64 & 14.54 & 8.28 & $24.74^{+}$ & 11.38 & 7.41 & 1.87 \\
\hline
\end{tabular}

15

$16{ }^{* * *}$ main effect for time, $p<.001$

$17{ }^{+}$main effect for sex, $p<.05$

$18 \quad$ sex $\times$ climate interaction effect, $p<.05$

$19{ }^{\mu}$ main effect for performance, $p<.05$

20 
$1 \quad$ Table 2.

2 Correlations between the Study Variables in the Performance Climate

3

4

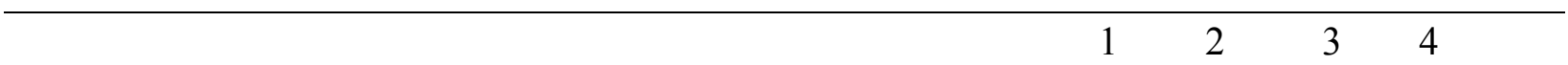

5

6 1. Number of Claimed Self-handicaps

$.88^{* * *} .09 \quad-.18$

7

2. Impact of Claimed Self-handicaps

$.08 \quad-.15$

8 3. Behavioral Self-handicapping (reverse scored)

.00

9 4. Performance

$10 \quad$ Note : ${ }^{*} p<.05 ; * * p<.01 ; * * * p<.001$.

11

12 
$1 \quad$ Table 3.

2 Correlations between the Study Variables in the Mastery Climate

3

4

$1 \quad 2 \quad 3 \quad 4$

5

6 1. Number of Claimed Self-handicaps $.85 * * * .05 \quad .05$

7

2. Impact of Claimed Self-handicaps

$.08 \quad .01$

8 3. Behavioral Self-handicapping (reverse scored)

9 4. Performance

10 Note : ${ }^{*} p<.05 ; * * p<.01 ; * * * p<.001$.

11 